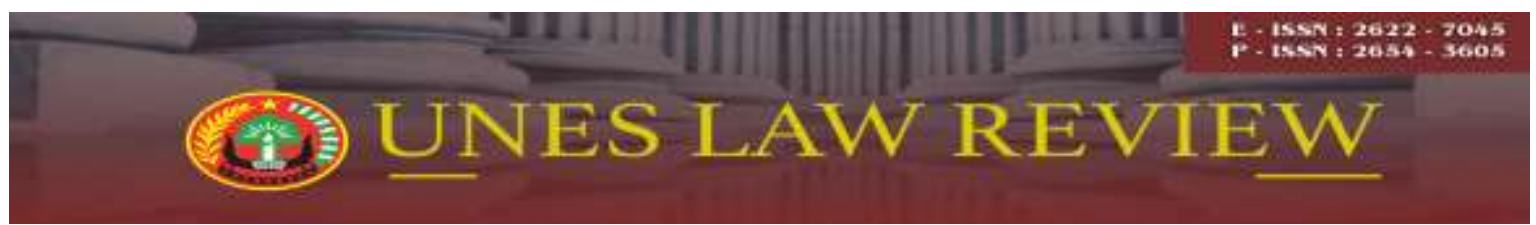

Email: uneslawreview@gmail.com

Online: http://review-unes.com/index.php/law

Volume 2, Issue 1, September 2019

\title{
PERLINDUNGAN HUKUM INDIKASI GEOGRAFIS ATAS MEREK KOPI TORAJA DAN KOPI GAYO YANG DIDAFTARKAN OLEH NEGARA LAIN
}

\author{
${ }^{1}$ Ayu Kumala Sari Hamidi, ${ }^{2}$ Iyah Faniyah \\ ${ }^{1}$ Program Magister Ilmu Hukum, Universitas Ekasakti, Padang \\ E-mail : yaya.hamidi92@gmail.com \\ ${ }^{2}$ Program Magister Ilmu Hukum, Universitas Ekasakti, Padang \\ E-mail : yaya.hamidi92@gmail.com
}

\begin{abstract}
The existence of IPR, especially Geographical Indications and Brands, is the basis of policy making in the world of Trade. Indonesia is a country that is rich in potential Geographical Indication products and then Law No. 20 of 2016 concerning Geographical Indications and brands for National Regulations and in TRIPS as International Arrangements. but there are still violations of cases regarding Geographical Indications and Trademarks and occur in Toraja coffee and Gayo coffee. The formulation of the problem in this research is how is the trademark legal law for Geographical Indications in the case of Toraja coffee and Gayo coffee registered by other countries? How is the legal settlement of the Violation of Brand Geographical Indications carried out by other Countries against Toraja coffee and Gayo coffee?The specification of this study is Descriptive Analysis. The approach is a normative juridical approach using secondary data obtained through library studies. The data is then analyzed qualitatively and presented in a qualitative descriptive form. Based on the results of research and analysis, answers can be obtained: 1) Legal protection against Toraja coffee and Gayo coffee registered by other countries, namely by registering the trademark to the Director General of Intellectual Property Rights and after obtaining a Geographical Indication certificate from the Director General of Intellectual Property Rights, the geographical indication of a product's brand it gets strong protection. 2) Legal settlement of brand violations and geographical indications of the brand of Toraja coffee and Gayo coffee are litigation methods carried out through the Commercial Court institution, for Toraja Coffee to be carried out at the Ujung Pandang Commercial Court and Gayo Coffee at the Medan Commercial Court.
\end{abstract}

Kata Kunci: Hukum Indikasi,

\section{PENDAHULUAN}

Merek merupakan suatu basis dalam perdagangan modern di era perdagangan bebas saat ini. Dikatakan demikian, karena merek dapat menjadi dasar perkembangan perdagangan modern yang ruang lingkupnya mencakup reputasi penggunaan merek atau 
goodwill (Abdulkadir Muhammad, 68:2001). Lambang kualitas, standar mutu, sarana menembus segala jenis pasar, dan diperdagangkan dengan jaminan guna menghasilkan keuntungan besar (Indo Trademark, 2018). Terdapatnya merek dapat lebih memudahkan konsumen membedakan produk yang akan dibeli oleh konsumen dengan produk lain sehubungan dengan kualitasnya, kepuasan, kebanggaan, maupun atribut lain yang melekat pada merek. Sistem pendaftaran merek di Indonesia pada dasarnya menganut Sistem Konstitutif yang berarti Hak merek ada karena pendaftarannya, sehingga hak merek tidak timbul secara otomatis. Sistem konstitutif pada dasarnya menggunakan prinsip first to file, dimana perlindungan hukum diberikan pada merek yang didaftar pertama kali dan sudah memenuhi syarat pendaftaran merek, dalam hal pembuktiannya juga apabila terjadi suatu sengketa, pemilik merek cukup menunjukan sertifikat pendaftaran merek yang dikeluarkan oleh Dirjen HKI bidang merek. Sertifikat merek tersebut merupakan sebuah bukti yang dikeluarkan oleh Dirjen HKI bahwa orang tersebut adalah pemilik sah dan berhak atas merek yang bersangkutan. Cara memperoleh dan Prosedur Pendaftaran Merek ada 3 cara agar dapat memperoleh hak atas merek, yaitu :

1. Melalui pendaftaran merek

2. Melalui pengalihan ha katas merek

3. Melalui lisensi

Dalam UU No. 20 Tahun 2016 tentang Merek dan Indikasi Geografis, prosedur pendaftaran Merek di atur di dalam Pasal 4 sampai Pasal 6. Prosedur tersebut di awali dengan Permohonan pendaftaran Merek diajukan oleh pemohon atau kuasanya kepada Menteri secara elektronik atau non-elektronik dalam bahasa Indonesia. Dalam Permohonan sebagaimana dimaksud pada ayat (1) harus mencantumkan:

a. tanggal, bulan, dan tahun Permohonan;

b. nama lengkap, kewarganegaraan, dan alamat Pemohon;

c. nama lengkap dan alamat Kuasa jika Permohonan diajukan melalui Kuasa;

d. warna jika Merek yang dimohonkan pendaftarannya menggunakan unsur warna;

e. nama negara dan tanggal permintaan Merek yang pertama kali dalam hal Permohonan diajukan dengan Hak Prioritas; dan

f. kelas barang dan/atau kelas jasa serta uraian jenis barang dan/atau jenis jasa. 
Permohonan ditandatangani Pemohon atau Kuasanya, kemudian Permohonan sebagaimana dimaksud pada ayat (1) dilampiri dengan label Merek dan bukti pembayaran biaya. Biaya Permohonan pendaftaran Merek ditentukan per kelas barang dan/atau jasa. Dalam hal Merek sebagaimana dimaksud pada ayat (4) berupa bentuk 3 (tiga) dimensi, label Merek yang dilampirkan dalam bentuk karakteristik dari Merek tersebut. Dalam hal Merek sebagaimana dimaksud pada ayat (4) berupa suara, label Merek yang dilampirkan berupa notasi dan rekaman suara. Permohonan sebagaimana dimaksud pada ayat (1) wajib dilampiri dengan surat pernyataan kepemilikan Merek yang dimohonkan pendaftarannya, Ketentuan lebih lanjut mengenai biaya Permohonan sebagaimana dimaksud pada ayat (5) diatur dengan Peraturan Pemerintah.

Permohonan untuk lebih dari 1 (satu) kelas barang dan/atau jasa dapat diajukan dalam satu Permohonan. Permohonan sebagaimana dimaksud pada ayat (1) harus menyebutkan jenis barang dan/atau jasa yang termasuk dalam kelas yang dimohonkan pendaftarannya. Ketentuan lebih lanjut mengenai kelas barang dan/atau jasa sebagaimana dimaksud pada ayat (1) diatur dengan Peraturan Menteri. Permohonan dan hal yang berkaitan dengan administrasi Merek yang diajukan oleh Pemohon yang bertempat tinggal atau berkedudukan tetap di luar wilayah Negara Kesatuan Republik Indonesia wajib diajukan melalui Kuasa. Pemohon sebagaimana dimaksud pada ayat (1) wajib menyatakan dan memilih alamat Kuasa sebagai domisili hukum di Indonesia. Ketentuan lebih lanjut mengenai Syarat dan Tata Cara Permohonan sebagaimana dimaksud dalam Pasal 4 sampai dengan Pasal 6 diatur dengan Peraturan Menteri.

Selain tata cara pendaftaran merek yang diatur oleh Undang-Undang Merek No.20 Tahun 2016 terdapat juga cara pendaftaran merek secara Internasional. Untuk sitem pendaftaran merek secara Internasional, yaitu yang lebih dikenal dengan sistem Madrid, diatur berdasarkan dua buah perjanjian Internasional yaitu Madrid Agreement Concerning the Internasional Registration of Marks (Agreement) dan the Protocolar Relating to Madrid Agreement (Protocol). Administrasi sistem Madrid ini dilaksanakan oleh World Intellectual Property Organization (WIPO) sebagai biro Internasional. Peran biro Internasional adalah mengatur pencatatan internasional dan mempublikasikan WIPO Gazette of International Marks. Setiap Negara yang merupakan anggota Paris Convention bisa menjadi salah satu anggota Agreement atau Protocol atau bahkan kedua perjanjian itu 
sekaligus. Negara-negara yang menjadi anggota Agrrement dan atau Protocol membentuk suatu wadah yang dinamakan the Madrid Union.

Selain mengenai perlindungan merek, di dalam pengaturan mengenai merek yang baru yaitu didalam UU No.20 Tahun 2016 mengenai Merek dan Indiksai Geografis telah menambahkan pengaturan mengenai Indikasi Geografis. Didalam pasal 1 ayat (6) UndangUndang tersebut disebutkan bahwa Indikasi Geografis yaitu suatu tanda yang menunjukkan daerah asal suatu barang dan/atau produk yang karena faktor lingkungan geografis termasuk faktor alam, faktor manusia atau kombinasi dari kedua faktor tersebut memberikan reputasi, kualitas, dan karakteristik tertentu pada barang dan/atau produk yang dihasilkan.

Didalam pengaturan Internasionalnya Masalah indikasi geografis diatur dalam Perjanjian Trade Related Aspect of Intellectual Property Rights (TRIPs), yang mewajibkan negara-negara anggota untuk menyusun peraturan tentang indikasi geografis dengan tujuan memberikan perlindungan hukum terhadap praktek atau tindakan persaingan curang. Dengan diratifikasinya Persetujuan Pembentukan Organisasi Perdagangan Dunia (WTO) oleh Indonesia pada tanggal 2 November 1994. Maka Indonesia wajib menerima persetujuan-persetujuan WTO dan yang menjadi lampirannya, termasuk TRIPs. Indonesia wajib menyesuaikan kerangka hukum nasionalnya sedemikian rupa sehingga sesuai dengan tingkat perlindungan atas enam jenis hak kekayaan intelektual sebagaimana terdapat dalam persetujuan TRIPs, termasuk perlindungan indikasi geografis. Salah satu langkah dalam pelaksanaan komitmen tersebut adalah Indonesia mengintegrasikan perlindungan indikasi geografis ke dalam UU No. 15 Tahun 2001 tentang Merek yang telah diganti dengan Undang-Undang No.20 Tahun 2016 tentang Merek dan Indikasi Geografis.

Dengan adanya perlindungan dalam kerangka TRIPs melalui ratifikasi negara terhadap pembentukan WTO, maka diharapkan dapat memberikan skema perlindungan secara internasional yang sistematis dan berkelanjutan bagi negara yang berpeluang dalam produk-produk indikasi geografis. Ironisnya bagi Indonesia, sampai saat ini perlindungan indikasi geografis tidak cukup mampu memberikan perlindungan terhadap produk-produk berpotensi indikasi geografis. Dalam lingkup internal, hingga saat ini jumlah sertifikat indikasi geografis masih tergolong sedikit dibandingkan dengan potensi indikasi geografis 
yang ada. Pada saat yang bersamaan, secara eksternal telah terdapat sejumlah pelanggaran terhadap indikasi geografis Indonesia.

Salah satu kasus pelanggaran yang terjadi adalah pendaftaran kopi toraja sebagai merek "TOARCO TORAJA" oleh perusahaan Key Coffee Inc Corporation Japan dengan nomor pendaftaran 75884722 lengkap dengan gambar rumah Toraja. Selain itu, kopi toraja juga pernah didaftarkan sebagaimerek "SULATCO KALOSI TORAJA COFFEE" dengan nomor pendaftaran 74547036, milik IFES Inc. Corporation California dan juga merek "SULATCO KALOSI TORAJA COFFEE" dengan gambar rumah Toraja,dengan nomor pendaftaran 74547000, milik IFES Inc. Corporation California (Sommeng, 91:2008). Hal ini memberikan akibat hukum dan kerugian bagi Indonesia karena menghalangi eksportir kopi dari Indonesia untuk memasukkan produk kopi yang menggunakan tanda nama Toraja. Pihak Jepang melarang pihak Indonesia melakukan kerjasama dengan pihak manapun selain dengan pihaknya, serta pihak Jepang bebas menjual kopi toraja ke pihak manapun tanpa izin sedangkan Indonesia tidak bebas mengekspor kopi toraja ke luar negeri. Didaerah asalnya sendiri, kopi toraja dipalsukan oleh pihak-pihak tertentu yaitu dengan memasukkan kopi (biji kering) dari luar Toraja dan kemudian dilabeli dengan nama kopi toraja dan dibawa kembali untuk dijual ke pasaran. Pencaplokan dengan menggunakan label Toraja ini, tentunya sangat merugikan pihak produsen, khususnya para petani di Toraja. Bukan hanya karena masalah finansial semata, namun citra kopi toraja sebagai salah satu kopi specialty yang terkenal di dunia dapat dirusak oleh oknum yang tidak bertanggungjawab.

Mengatasi masalah tersebut, maka perlindungan hukum berupa sertifikat indikasi geografis bagi kopi arabika toraja merupakan sebuah keharusan. Apalagi berdasarkan peraturan Internasional dalam WTO menyatakan bahwa setiap negara anggota tidak diwajibkan untuk melindungi produk indikasi geografis yang tidak dilindungi di negara asalnya. Hal ini berarti bahwa untuk mendapatkan alas hukum perlindungan domestik dan internasional, maka perlindungan di dalam negeri berupa sertifikat indikasi geografis merupakan langkah yang paling utama. Hal ini penting mengingat gaung kopi arabika toraja di dunia internasional dan dalam negeri sebagai kopi yang berkualitas dengan cita rasa yang khas dan hanya berasal dari Toraja sudah sangat diketahui, dengan kata lain, 
kopi arabika toraja adalah produk berpotensi indikasi geografis yang bernilai ekonomis tinggi.

Pada tanggal 25 Januari 2014, sertifikat indikasi geografis kopi arabika toraja diserahkan oleh Kementrian Hukum dan HAM kepada Pemerintah Toraja. Hal ini tentunya tidak terlepas dari berbagai upaya para aktor domestik dalam berbagai aspek yang terkait dan berbagai kendala yang dihadapi. Maka dari itu, berdasarkan pada kondisi yang dijelaskan sebelumnya, penelitian ini bertujuan untuk menjelaskan upaya yang dilakukan oleh pihak-pihak yang terkait dalam berbagai aspek yang terkait. Selain itu, tesis ini berusaha menjelaskan kendala yang dihadapi dalam proses memperjuangkan perlindungan indikasi geografis kopi arabika toraja.

Selain masalah yang menyangkut kopi toraja ini, ada contoh lain dari kasus yang sama mengenai Indikasi Geografis yaitu kasus merek kopi Gayo yangterjadi adalah kopi gayo yang diketahui didaftarkan oleh pengusaha Belanda sebagai merek dagang di Belanda, sehingga eksportir kopi Daerah Gayo, Nanggroe Aceh Darussalam, tidak bisa mengekspor komoditas itu dengan menggunakan merek Gayo. Kopi Gayo berpotensi didaftarkan sebagai produk indikasi geografis karena unik dan memiliki karakteristik. Kedudukan hak merek Kopi Gayo yang dimiliki oleh CV Arvis Sanada sempat diambil alih oleh perusahaan kopi milik Belanda yang mengklaim bahwa merek Kopi Gayo merupakan merek dagangnya yang sah, CV Arvis Sanada dilarang untuk mengekspor ke Eropa dikarenakan Holland Coffee melarang CV Arvis Sanada menggunakan kata "Gayo". Holland Coffee selalu menghambat dan mempermasalahkan penggunaan kata "Gayo" pada produk kopi yang di ekspor, oleh CV Arvis Sanada, ke pasar Belanda.

Berdasarkan uraian diatas terdapat masalah yang menarik untuk ditinjau lebih lanjut tentang hak Kekayaan Intelektual, khususnya dibidang Merek dalam hal indikasi geografis suatu merek dan mengkajinya dalam suatu karya ilmiah yang berjudul Perlindungan Hukum Indikasi Geografis Atas Merek Kopi Toraja dan Kopi Gayo Yang Didaftarkan Oleh Negara Lain.

\section{METODE PENELITIAN}

Pendekatan yang digunakan dalam penelitian ini hanya pendekatan yuridis normatif dengan data sekunder yang diperoleh melalui studi kepustakaan. Data tersebut kemudian di analisis secara kualitatif dan disajikan dalam bentuk deskriptif kualitatif. 


\section{HASIL PENELITIAN}

\section{Sejarah Kopi Toraja}

Kopi Toraja, merupakan salah satu varian kopi yang paling populer dan memiliki kualitas terbaik yang dimiliki oleh Indonesia. Di samping kopi Gayo dan Luwak, kopi yang memiliki nama latin Celeber Kalosi ini juga dikenal oleh para pecinta kopi dari seluruh dunia. Selain memiliki rasa yang khas kopi ini juga memiliki karakteristik yang unik. Di bawah ini akan ada pembahasan mengenai kopi yang menjadi favorit pecinta kopi dari seluruh dunia tersebut. Mulai dari tempat asal, karakteristik, hingga harga kopi Toraja. Kopi ini berasal dari Tana Toraja yang berada di provinsi Sulawesi Selatan. Tana Toraja memang sudah dikenal sebagai tujuan wisata yang wajib dikunjungi. Faktanya tempat ini juga sudah ditetapkan sebagai warisan dunia yang harus dijaga dan dilestarikan oleh United Nations Educational, Scientific and Cultural Organization (UNESCO). Tidak hanya terkenal dengan lahan pegunungan dan adat istiadatnya saja, Tana Toraja juga sangat dikenal dengan biji kopinya.

Kopi ini terletak di lokasi Tana Toraja yang berada di atas pegunungan dengan rata-rata ketinggian antara 1.000- $1.500 \mathrm{mdpl}$. Tana Toraja memiliki iklim tropis basah dan curah hujan sedang-tinggi sehingga kondisi tersebut sangat baik bagi tanaman kopi. Orangorang Gowa berlayar membawa kopi menuju Toraja. Orang Gowa berlayar menuju pelabuhan Suppa (sekarang wilayah Parepare), kemudian berjalan kaki melewati pegunungan Enrekang menuju Toraja. Tanaman kopi, dibawa pertama kali oleh para saudagar Arab yang mendatangi Makassar. Diperkenalkan sebagai sebuah minuman kekuatan dan penambah vitalitas, membuat mata terjaga dan bahkan tak tidur. Dengan cepat, kabar mengenai khasiat kopi pun tersebar. Untuk membiakkannya, dibutuhkan tempat tinggi dan bersuhu dingin, dan Toraja memenuhi kriteria itu.

Kopi toraja telah digunakan di luar negeri yaitu di negara Jepang dan didaftarkan sebagai merek TOARCO TORAJA. Indonesia terlambat dalam mendaftarkan merek kopi toraja ini dan kesadaran itu timbul setelah mengalami kerugian. Kopi ini didaftarkan dengan merek Toarco Toraja Coffe dengan nomor pendaftaran 358424 yang mempunyai tanggal kadaluwarsa 24 Februari 2005, selanjutnya diperpanjang dengan nama Toarco 
Toraja Coffee dengan nomor pendaftaran 15922 dan tanggal kadaluwarsa 24 Februari 2025. Sementara itu Masyarakat Perlindungan Indikasi Geografis (MPIG) kopi toraja mendaftarkan kopi arabika toraja sebagai indikasi geografis terdaftar. Kopi Arabika Toraja terdaftar sebagai indikasi geografis pada tanggal 9 Oktober 2013 dengan nomor IG. 00.2012. 000007.

Ketenaran Kopi Toraja kemudian dimanfaatkan oleh perusahaan Key Coffee Inc. dari Jepang dengan mendaftarkan Merek "Toarco Toraja" dengan nomor pendaftaran 75884722 di Jepang Pada tanggal 14 Januari 1977. Merek tersebut selain menampilkan kata "Toraja" juga rumah adat Toraja sebagai latar merek. Hal ini terjadi karena tidak adanya undang-undang nasional yang mengatur tentang indikasi geografis dan indikasi asal pada saat didaftarkannya Merek Kopi Toraja oleh perusahaan Key Coffee Inc. pada tahun 1977 di Jepang.

\section{Sejarah Kopi Gayo}

Perkebunan kopi yang telah dikembangkan sejak tahun 1908 ini tumbuh subur di Kabupaten Bener Meriah, Aceh Tengah dan sebagian kecil wilayah Gayo Lues. Ketiga daerah yang berada di ketinggian $1200 \mathrm{~m}$ di atas permukaan laut tersebut memiliki perkebunan kopi terluas di Indonesia, yaitu sekitar 81.000 hektar. Masing-masing 42.000 hektar berada di Kabupaten Bener Meriah, selebihnya (39.000 hektar) di Kabupaten Aceh Tengah. Masyarakat Gayo berprofesi sebagai petani kopi dengan dominasi varietas Arabika. Produksi kopi arabika yang dihasilkan dari Tanah Gayo merupakan yang terbesar di Asia.

Amir Hamzah, kepala Badan Penelitian Kopi Gayo, mengatakan kopi Gayo Arabica tidak dapat diperoleh dari tempat lain karena jenis tanah yang khas di dataran tinggi. Kondisi cuaca dan ketinggian 1.200 meter di perkebunan juga memainkan peran kontribusi karena keduanya ideal untuk menanam kopi. Daya tarik besar bagi eksportir kopi dunia karena penanaman kopi gayo menggunakan metode organik dan dari varietas unggul. Komoditi kopi ini menjadi target menjadikan harganya kian naik karena permintaan akan kopi organik. Sekitar $80 \%$ petani kopi di Aceh Tengah memelihara perkebunan kopi organik. Perekonomian di sekitar kabupaten dan Aceh Tengah sangat menggantungkan pada harga kopi pasar di dunia. Tentunya setiap kenaikan akan 
berdampak besar bagi penduduk lokal yang hampir seluruhnya hidup dengan berkebun kopi.

Pada tanggal 15/07/1999 kata "Gayo Mountain Coffee" telah didaftarkan oleh European Coffee Bv yang beralamat Zwarteweg 6 BNL- 1412 GD Naarden Paises Bajos melalui CTM daftar 001242965, kelas 30 dengan jenisbarang Coffee, tea, cocoa, sugar and artificial coffee. Berdasarkan adanya sertifikat merek European BV melalui Holland Coffee telah melayangkan somasi kepada PT. Arvis Sanada, perusahaan eksportir kopi nasional yang dimiliki oleh putra asal Gayo berkedudukan di Medan Sumatera. Masyarakat Perlindungan Kopi Gayo (MPKG) telah mendaftarkan dengan nomer dan tanggal pendaftaran ID G 000000005 (28 April 2010) serta nomor agenda IG.00.2009.000003.

Tahun 1999 mendaftarkan nama "Gayo" sebagai merek dagang kopi mereka di Belanda (Gayo Mountain Coffee). Dengan adanya merek dagang tersebut maka secara tidak langsung masyarakat Gayo Aceh telah kehilangan hak atas penggunaan nama mereka. Di samping itu juga Indonesia jelas dirugikan karena tidak dapat melakukan ekspor kopi Gayo.

\section{Upaya Penyelesaian Sengketa Dalam Melindungi Indikasi Geografis Merek Kopi Toraja dan Kopi Gayo}

Dalam penyelesaian sengketa nasional dapat dilakukan dengan 2 (dua) cara yaitu melalui pengadilan dan di luar pengadilan. Penyelesaian melalui jalur pengadilan biasa juga disebut sebagai litigasi, sebaliknya penyelesaian sengketa di luar pengadilan disebut sebagai non litigasi. Cara penyelesaian sengketa di luar pengadilan telah diatur dalam UU No. 30 Tahun 1999 tentang Arbitrase dan Alternatif Penyelesaian Sengketa. Beberapa cara penyelesaian sengketa tersebut adalah: arbitrase, konsultasi, negosiasi, mediasi, konsiliasi, dan penilaian ahli. Dalam penyelesaian sengketa secara Internasional ada yang diatur dalam kerangka TRIPs dan Dalam Kerangka WTO. Di dalam WTO diatur beberapa cara penyelesaiannya, beberapa di antaranya yaitu; a) Konsultasi, b) Jasa-Jasa Baik, Konsiliasi, dan Mediasi, c) Badan Penyelesaian Sengketa (Dispute Settlement Body / DSB) dan Pembentukan Panel, d) Badan Banding (Appellate Body).

PEMBAHASAN

Perlindungan Hukum Terhadap Indikasi Geografis Merek Terdaftar Kopi Toraja dan Kopi Gayo Yang Didaftarkan Oleh Negara Lain. 
Pengaturan perlindungan hukum terhadap indikasi geografis merek terdiri dari perlindungan nasional dan internasional. Di Indonesia peraturan mengenai perlindungan hukum di atur di dalam UU No.15 tahun 2001 Tentang Merek dan untuk pengaturan internasional di atur di dalam TRIPs dan WTO. Di dalam pengaturan internasional yaitu di dalam TRIPs ada dua cara yaitu secara passive atau negative atau non registration protection system. Negara-negara anggota TRIPs ada yang mengatur perlindungan Indikasi Geografis secara passive atau negative atau non registration protection system. Seiring dengan berjalannya waktu, definisi dan perlindungan terhadap Indikasi Geografis mengalami perkembangan. Beberapa negara memakai perlindungan dengan mengacu The WIPO Model Law. Tidak adanya suatu kewajiban kepada pihak-pihak yang berkepentingan untuk melakukukan pendaftaran barang yang berpotensi Indikasi Geografis. Perlindungan juga dapat diberikan secara otomatis atau passive protection dengan tanpa adanya pendaftaran. Seperti halnya di Singapura tidak mensyaratkan adanya pendaftaran atas Indikasi Geografis. The 1998 Geographical Indications Act. Memberikan perlindungan kepada pemilik Indikasi Geografis secara otomatis seperti halnya perlindungan kepada hak cipta atau copyrights.

Indonesia berdasarkan pasal 56 ayat (2) UU Merek menganut system pendaftaran positive protection system, yang mensyaratkan Indikasi Geografis terlebih dahulu didaftarkan, dalam hal ini dilakukan secara kolektif atau kelembagaan, bukan perseorangan. Artinya kepemilikannya pun bersifat kolektif-komunal. Dalam sistem HKI yang positif atau aktif atau positive/registration protection system, pihak-pihak yang berkepentingan akan menikmati perlindungan hukum jika pihak-pihak teresbut telah mengajukan pendaftaran terhadap IG. Sedangkan sebaliknya, dalam passive atau negative atau non registration protection system pihak-pihak (interested party) tidak perlu melakukan pendaftaran, karena secara otomatis IG mendapat perlindungan.

Setiap produk yang telah memperoleh sertifikat indikasi geografis akan mendapatkan perlindungan hukum yang kuat. Untuk menunjukkan indikasi geografis tersebut, setiap produk memiliki logo Indikasi Geografis Indonesia. Tanda yang digunakan sebagai Indikasi Geografis dapat berupa etiket atau label yang dilekatkan pada barang yang dihasilkan. Tanda tersebut dapat berupa nama tempat, daerah, atau wilayah, kata, gambar, 
huruf, atau kombinasi dari unsur-unsur tersebut. Sebelum produk-produk tersebut mendapatkan perlindungan hukum terlebih dahulu masyarakat atau produsen serta pemerintah daerah yang memiliki indikasi geografis tersebut mendaftarkan produknya ke Dirjen Hak Kekayaan Intelekual. Seperti kasus yang terjadi pada Kopi Toraja dan Kopi Gayo, pihak negara Jepang dan Belanda yang awalnya melakukan kerja sama dengan Indonesia pada akhirnya mendaftarkan sendiri hasil produk asal dari negara Indonesia dengan memakai nama dan logo yang sama dengan Indikasi di Indonesia. Hal ini tentu karena kurangnya perlindungan hukum dan kepastian hukum yang seharusnya negara mampu untuk melindungi dan mampu menjamin hak dan kewajiban setiap warga negara dan indikasi geografis produk asal barang/jasa negaranya. Oleh sebab itu alasan yang kuat juga bagi pihak masyarakat, produsen maupun pemerintah daerah asal indikasi geografis merek kopi Toraja dan Kopi Gayo melakukan gugatan terhadap negara lain yang telah mengambil alih apa yang seharusnya menjadi milik masyarakat Indonesia, dan masyarakat juga mengalami kerugian atas hal itu. Hal terpenting yang dibutuhkan dalam perlindungan indikasi geografis ini adalah pendaftaran ke Direktorat Jendaral HKI. Jika suatu indikasi geografis telah terdaftar di Direktorat Jendral HKI maka pemerintah wajib melakukan perlindungan terhadap indikasi geografis merek tersebut.

\section{Upaya Hukum Yang Dilakukan Dalam Menyelesaikan Kasus Pelanggaran Indikasi Geografis Merek Terdaftar Atas Kopi Toraja Dan Kopi Gayo}

Upaya hukum yang dilakukan oleh pemilik indikasi geografis adalah dengan cara litigasi yaitu penyelesaian yang ditempuh melalui lembaga Pengadilan. Hal tesebut dilakukan setelah masyarakat mengajukan gugatan ke Pengadilan Negeri (Pengadilan Niaga) tempat kedudukan asal daerah yang memiliki kasus mengenai indikasi geografis tersebut. Dasar dari pengajuan gugatan secara hukum nasional adalah Pasal 66 menjelaskan Pelanggaran atas indikasi geografis mencakup:

1. Pemakaian indikasi geografis, baik secara langsung maupun tidak langsung atas barang dan/atau produk yang tidak memenuhi Dokumen Deskripsi indikasi geografis;

2. Pemakaian suatu tanda indikasi geografis, baik secara langsung maupun tidak langsung atas barang dan/atau produk yang dilindungi atau tidak dilindungi dengan maksud untuk: 
a. menunjukkan bahwa barang dan/atau produk tersebut sebanding kualitasnya dengan barang dan/atau produk yang dilindungi oleh indikasi geografis;

b. mendapatkan keuntungan dari pemakaian tersebut; atau

c. Mendapatkan keuntungan atas reputasi indikasi geografis

3. Pemakaian indikasi geografis yang dapat menyesatkan masyarakat sehubungan dengan asal-usul geografis barang itu;

4. Pemakaian indikasi geografis oleh bukan pemakai indikasi geografis terdaftar;

5. Peniruan atau penyalahgunaan yang dapat menyesatkan sehubungan dengan asal tempat barang dan/atau produk atau kualitas barang, dan/atau produk yang terdapat pada:

a. pembungkus atau kemasan;

b. Keterangan dalam iklan;

c. keterangan dalam dokumen mengenai barang dan/atau produk tersebut; atau

d. informasi yang dapat menyesatkan mengenai asal-usulnya dalam suatu kemasan.

6. Tindakan lainnya yang dapat menyesatkan masyarakat luas mengenai kebenaran asal barang dan/atau produk tersebut. Undang-Undang No. 15 Tahun 2001 tidak secara tegas menjelaskan pelanggaran atas indikasi geografis, tetapi pemegang hak indikasi geografis dapat mengajukan gugatan.

Dalam Pasal 22 ayat (2) Perjanjian TRIPs juga dapat dijadikan dasar bagi masyarakat dan pemerintah daerah mengajukan gugatan. Karena didalam pasal perjanjian tersebut berbunyi: Negara anggota wajib menyediakan sarana hukum bagipihak yang berkepentingan untuk melarang digunakannya cara apapun dalam pemberian tanda terhadap barang yang memberikan petunjuk atau kesan yang menyesatkan masyarakat bahwa barang bersangkutan berasal dari wilayah lain selain dari wilayah asal yang sebenarnya dari barang tersebut.

Dari uraian di atas maka dapat disimpulkan bahwa Jepang dan Belanda sebagai negara tergugat karena melanggar Pasal 22 ayat (2) Perjanjian TRIPs karena tidak menyatakan kebenaran tempat asal barang, dimana Kopi Toraja dan Kopi Gayo adalah salah satu wilayah geografis di Indonesia. Dalam perjanjian TRIPs tidak melarang penggunaan merek yang memakai Indikasi Geografis dan Indikasi Asal suatu daerah atau wilayah selama barang/produk yang diperdagangkan itu tidak menyesatkan masyarakat, dengan kata lain bahwa barang yang diperdagangkan itu harus berasal dari wilayah asal 
atau Indikasi Asal yang digunakan dalam mereknya. Tetapi sebaliknya jika penggunaan merek yang memakai Indikasi Geografis dan Indikasi Asal suatu daerah, dimana barang yang diperdagangkan tersebut tidak berasal dari daerah asal atau Indikasi Asal yang digunakan dalam mereknya, maka merek tersebut dapat dibatalkan. Hal tersebut dapat dilihat dalam Pasal 22 ayat (3) Perjanjian TRIPs.

Akan tetapi, Hasil dari penyelesaian atas kasus Kopi Toraja dan Kopi Gayo ini masih belum final dan mempunyai kekuatan hukum yang tetap meskipun gugatan ini telah didaftarkan ke Pengadilan Niaga. Hanya saja dari kasus ini kedua produk indikasi geografis tersebut telah mendapatkan sertifikat indikasi geografis dari Dirjen HKI dan Mentri. Dalam kedua kasus ini, pihak negara lain memiliki merek dagang atas hasil dari produk indikasi geografis sedangkan negara Indonesia memiliki Indikasi Geografis atas produk tersebut.

\section{PENUTUP}

\section{Kesimpulan}

Perlindungan hukum terhadap merek dilihat dari indikasi geografis dalam kasus kopi toraja yang di daftarkan oleh negara Jepang dan kopi gayo yang didaftarkan oleh negara Belanda yaitu dengan cara mendaftarkan merek tersebut ke Dirjen Hak Kekayaan Intelektual. Setelah mendapatkan sertifikat Indikasi Geografis dari pihak Dirjen HKI barulah indikasi geografis merek suatu produk tersebut mendapat perlindungan yang kuat.

Penyelesaian hukum atas pelanggaran merek dan indikasi geografis yang dilakukan oleh negara lain terhadap merek kopi toraja dan kopi gayo adalah cara Litigasi yaitu penyelesaian yang di tempuh dengan melalui lembaga Pengadilan. Lembaga Pengadilan yang digunakan dalam penyelesaian kasus ini yaitu Pengadilan Niaga.

\section{Saran}

Sebaiknya pihak pemerintah Indonesia lebih serius dalam melakukan upaya Perlindungan Merek terhadap produk khas Indonesia agar tidak diklaim lagi oleh negara lain. Dan juga sosialisasi menyeluruh ke masyarakat akan pentingnya pengetahuan mengenai perlindungan merek di Indonesia agar tidak lagi terjadinya kerugian bagi masyarakat Indonesia terlebih masyarakat yang bertindak sebagai petani di daerah yang mempuyai indikasi geografis. 
Sebaiknya pihak pemerintah Indonesia dan pelaku usaha melakukan pembenahan dalam pendokumentasian aset nasional agar kasus pendaftaran merek dagang Indonesia oleh perusahan di Belanda dan Jepang tidak terulang lagi, terlebih mereka lebih jeli dan lebih menghargai nilai komersial dari aset tersebut.

\section{DAFTAR PUSTAKA}

\section{Buku Teks :}

A.B Susanto dan Himawan Wijanarko, Power Branding-Membangun Merek Unggul dan Organisasi Pendukungnya, Mizan Publika, Jakarta, 2004

Adrian Sutedi, Hak Atas Kekayaan Intelektual, Cetakan 1, Sinar Grafika, Jakarta, 2009

Agung Sudjatmiko, Perlindungan Hukum Hak Atas Merek, Yuridika, Vol. 15 No. 5 September-Agustus, 2000

Djulaeka,Konsep Perlindungan Hak Intelektual: Prespektif Kajian Filosofis HAKI Kolektif-Komunal, Setara Press, Malang, 2014.

Gatot Supramono, Menyelesaikan Sengketa Merek Menurut Hukum Indonesia, PT Rineke Cipta, Jakarta, 2008.

I Gede Agus Kurniawan, Pengaturan Penghentian Pemakaian Indikasi Geografis Pada Merek Terdaftar Oleh Pihak Lain Yang Tidak Berhak ( Studi Komparatif Beberapa Negara), Jurnal Program, Magister Universitas Udayana, Denpasar 2013.

Muhammad Firmansyah, Tata-Tata Cara Mengurus HKI, Transmedia, Jakarta, 2008.

O.C.Kaligis, Teori dan Praktek Hukum Merek Indonesia, PT Alumni, Bandung, 2008.

\section{Pustaka Primer (Journal) :}

Agreement on trade-related aspect of intellectual property rights' terdapat dalam situs http://www.wto.org/english/docs e/legal e/27-tips 01 e.htm.

Trademark in General',,terdapat pada situs resmiWIPOhttp://www.wipo.int//ma drid/en/faq/t rademark.html\#p3 21.

Indo Trademark, Selamat Datang Di Situs Kami, http://indotrademark.com/. DGIP. Indikasi Geografis Terdaftarhttp://www. dgip. go. Id

https://id.wikipedia.org/wiki/Kopi_gayo

https://media.neliti.com/media/pu blicatio ns/60172-ID-optimalisasi- perlindungan-hukumterhadap.pdf

www. keycoffee. co. jp

Budi Agus Riswandi, Makalah Seminar Nasional "Mencari Bentuk dan Substansi Pengaturan Indikasi Geografis", Sekretariat Wakil Presiden RI, IIPS Komda DIY, dan Fakultas Hukum Universitas Islam Indonesia Yogyakarta,2009

Peraturan Undang-Undang : 
Undang-Undang Nomor 15 Tahun 2001 tentang Merek, sebagai pengganti UndangUndang No.14 Tahun 1997

Undang-Undang Nomor 20 Tahun 2016 tentang Merek dan Indikasi Geografis

Peraturan Pemerintah No.23 Tahun 1993 tentang Tata Cara Pendaftaran Merek

Peraturan Pemerintah No.32 Tentang Komisi Banding Merek

Peraturan Pemerintah No. 51 Tahun 2007 tentang Indikasi Geografis

Keputusan Menteri Kehakiman Republik Indonesia No.M.03-HC.02.01 Tahun 1991 tentang Penolakan Pendaftaran Merek Terkenal Milik Orang Lain atau Milik Badan Lain

Keputusan Menteri Kehakiman Republik Indonesia No.M.09-PR.07.08 Tahun 1999 tentang Penunjukan Kantor wilayah Departemen Kehakiman Untuk Menerima Permohonan HKI

Japan International Cooperation Agency / JICA (Undang-Undang Anti Persaingan Curang Jepang) secara drastis direvisi untuk pertama kalinya dalam kurun waktu 60 tahun sejak diundangkan pada tahun 1934. Amandemen ini diundangkan tanggal 19 mei 1993, dan mulai berlaku sejak bulan mei 1994 dengan beberapa hal perubahan. 